\title{
Yoke Device
}

National Cancer Institute

\section{Source}

National Cancer Institute. Yoke Device. NCI Thesaurus. Code C50273.

A structural device designed to connect multiple objects. 